\title{
PENGEMBANGAN EDUCATIVE GAME BERBASIS APLIKASI ANDROID UNTUK MEMFASILITASI KETERAMPILAN MEMBACA ANAK USIA 5-6 TAHUN
}

\author{
Alvi Sufiyanti Febriani ${ }^{1}$, Edi Hendri Mulyana ${ }^{2}$, Taopik Rahman ${ }^{3}$ \\ ${ }^{1}$ Program Studi PGPAUD UPI Kampus Tasikmalaya \\ ${ }^{2}$ Program Studi PGPAUD UPI Kampus Tasikmalaya \\ ${ }^{3}$ Program Studi PGPAUD UPI Kampus Tasikmalaya \\ Email : alfi.sufiyati@gmail.com
}

(Received: November 2018; Accepted: November 2018; Published: Desember 2018)

\begin{abstract}
This research is based on the magnitude of children's interest in smartphone until they ignore to study. Most children who play smartphone are only for watching videos and playing games which are attractive to them. Therefore, the researcher designed an educative game Android-based application so they can play smartphone by not ignoring the development of reading skill. The purpose of this research is to describe the design of development, appropriateness, and product testing.This research uses the Design Based Research (DBR) method developed by Reeves. Data collection is done by observation, expert judgment, and documentation techniques. The setting and subject of this research are 6 kindergarten children in group B Nyimas Oyoh Kindergarten and 2 children from the researcher's home. The Educative game android-based application development uses Adobe Flash Player for the main software. After validating, phase I trial, revision, and phase II trial, this educative game is appropriate to be used to facilitate reading skill of children aged 5-6 years. The research produced product that is an educative game learning with Uvi in application installed at smartphone with a minimum version of Jelly Bean, and a guide book on educative game learning with Uvi.
\end{abstract}

Keywords: Educative Game, Android, Reading Skill Of Children Aged 5-6 Years.

\begin{abstract}
ABSTRAK
Penelitian ini dilatarbelakangi karena besarnya ketertarikan anak pada smartphone sehingga mengabaikan belajar. Kebanyakan anak yg bermain smartphone hanya untuk menonton video-video dan bermain permainan yang menarik bagi anak. Oleh karena itu, peneliti merancang educative game berbasis aplikasi android agar anak dapat bermain smartphone dengan tidak mengabaikan perkembangan keterampilan membacanya. Tujuan dari penelitian ini yaitu mendeskripsikan rancangan pengembangan, kelayakan, dan uji coba produk. Penelitian ini menggunakan metode Design Based Research (DBR) yang dikembangkan oleh Reeves. Pengumpulan data dilakukan dengan teknik observasi, expert judgment, dan dokumentasi. Setting dan subjek penelitian ini adalah 6 orang anak kelompok B TK Nyimas Oyoh dan 2 orang anak dari lingkungan rumah. Pengembangan Educative game berbasis aplikasi android ini menggunakan Adobe Flash Player sebagai software utamanya. Setelah melakukan validasi, uji coba tahap I, revisi, dan uji coba tahap II, educative game ini layak digunakan dalam memfasilitasi keterampilan membaca anak usia 5-6 tahun. Penelitian ini menghasilkan produk berupa educative game belajar Bersama Uvi dalam bentuk aplikasi yang dapat digunakan di perangkat keras berupa smartphone dengan versi minimal Jelly Bean, dan buku panduan penggunaan educative game belajar bersama Uvi.
\end{abstract}

Kata Kunci: Educative Game, Android, Kemampuan Membaca Anak 5-6 Tahun 


\section{PENDAHULUAN}

Sebagai insan mulia dalam bidang pendidikan sudah selayaknya kita mampu mengikuti perkembangan zaman yang dimana kita harus dituntut untuk dapat menggunakan serta mengaplikasikan berbagai macam teknologi modern terutama dalam hal pengembangan aplikasi guna membantu atau mempermudah suatu pekerjaan. Dengan penggunaannya yang sangat mudah, tidak jarang teknologi modern pun digunakan oleh anak usia dini untuk sekedar menonton video dan bermain permainan yang menyenangkan bagi mereka. Dalam ranah pendidikan, pendidikan anak usia dini merupakan pendidikan yang sangat dibutuhkan bagi anak karena proses pertumbuhan serta perkembangan anak terjadi pada rentang usia 0-6 tahun yang dimana terjadi sangat pesat sehingga anak membutuhkan pelayanan yang sesuai dengan rentang usianya. Berdasarkan Undang-Undang RI No. 20 Tahun 2003 tentang Sistem Pendidikan Nasional (Dalam Yuliani, 2013, hlm. 21) yang dimaksud dengan Pendidikan Anak Usia Dini adalah suatu upaya pembinaan yang ditujukan kepada anak sejak lahir sampai dengan usia enam tahun yang dilakukan melalui pemberian rangsangan pendidikan untuk membantu pertumbuhan dan perkembangan jasmani dan rohani agara anak memiliki kesiapan dalam memasuki pendidikan lebih lanjut. Penggunaan media pembelajaraan berfungsi untuk membantu atau memepermudah pendidik dalam proses pembelajaran.

Menurut Slamento, dkk., 2003 dalam buku Media Pendidikan Berbasis Powerpoint untuk Anak Usia Dini (2015, hlm.4) menyatakan bahwa media pendidikan memiliki peran yang sangat penting untuk menciptakan keberlangsungan proses pendidikan secara efektif, efisien, dan bermakna. Media pendidikan merupakan alat dalam bentuk hardware maupun software yang dapat digunakan untuk menyalurkan atau menyampaikan pesan bermakna dari pendidik sebagai pengirim kepada anak didik sebagai penerima yang bertujuan sebagai stimulus pengembangan pola pikir/pengetahuan, perasaan/emosi, dan perilaku/psikomotorik berdasarkan minat anak didik.

Menurut Gerlach \& Ely (1971) media adalah manusia, materi, atau kejadian yang membangun kondisi yang membuat siswa mampu memperoleh pengetahuan keterampilan, atau sikap. Dalam pengertian ini, guru, buku teks, dan lingkungan sekolah merupakan media. Secara lebih khusus, pengertian media dalam proses belajar mengajar cenderung diartikan sebagai alat-alat grafis, fotografis, atau elektronis untuk menangkap, memproses, dan menyusun kembali informasi visual atau verbal.

Di dalam pembelajaran anak usia dini, anak dituntut dan ditekankan untuk mampu menguasai empat keterampilan berbahasa. Adapun keempat keterampilann tersebut adalah keterampilan menyimak, membaca, berbicara, dan menulis. Keterampilan membaca merupakan salah satu keterampilan yang diperlukan oleh pembelajar atau anak dalam proses pembelajaran di dalam kelas, dikarenakan membaca merupakan kegiatan yang harus dikuasai secara penuh dalam proses 
pembelajaran. Akan tetapi, masih banyak pembelajar atau anak yang masih kurang menguasai keterampilan membaca ini.

Pentingnya kemampuan membaca bagi anak usia dini menurut Mary Leonhardt (1999:27) dalam Metode Pembelajaran Bahasa, Nurbiana Dhieni,dkk,Universitas Terbuka, Jakarta adalah Anak yang senang membaca akan membaca dengan baik, sebagian waktunya digunakan untuk membaca, mempunyai rasa kebahasaan yang lebih tinggi. Mereka akan berbicara, menulis dan memahami gagasan-gagasan rumit secara lebih baik. Kegemaran membaca akan memberikan berbagai perspektif dan wawasan yang lebih luas kepada anak dalam berbagai hal dan akan mampu mengembangkan pola berpikir kreatif anak. Kegemaran membaca harus ditingkatkan sejak dini, karena anak yang gemar membaca pada dasarnya memiliki kemampuan berbahasa yang lebih mempuni. Kemampuan membaca anak usia dini banyak mempengaruhi kemampuan intelegensi anak dikarenakan semakin dini anak belajar membaca semakin gemar pula anak dalam membaca. Tetapi, saat ini anak lebih senang menoton video ataupun bermain permainan dalam smaertphone sehingga kurangnya ketertarikan anak dalam mengembangkan keterampilan membacanya.

Pendidikan anak usia dini adalah suatu upaya pembinaan yang ditunjukan kepada anak usia dini (0-6 tahun) yang dilakukan melalui pemberian stimulasi pendidikan untuk membantu pertumbuhan dan perkembangan jasmani dan rohani agar memiliki kesiapan dalam memasuki pendidikan dasar dan kehidupan tahap berikutnya
Wijana,dkk,2012:2,5). Pendidikan anak usia dini sangatlah penting karena pencapaian perkembangan anak sangat pesat pada usia 0-6 tahun sehingga anak membutuhkan stimulus yang tepat agar anak dapat berkembang sesuai dengan tahapan perkembangannya. Mengacu pada permasalahan yang telah dijabarkan sebelumnya, peneliti tertarik untuk mencoba menggunakan educative game berbasis aplikasi android untuk memfasilitasi keterampilan membaca anak usia 5-6 tahun agar meskipun anak bermain smartphoe tetapi anak juga dapat mengembangkan keterampilan membacanya.

\section{TINJAUAN PUSTAKA} Hakikat Anak Usia Dini

Sugiyono (2013: hlm. 6) Anak usia dini adalah sosok individu yang sedang menjalani suatu proses perkembangan dengan pesat dan fundamental bagi kehidupan selanjutnya. Anak usia dini berada pada rentang usia 0-8 tahun. Pada masa ini proses pertumbuhan dan perkembangan dalam berbagai aspek sedang mengalami masa yang cepat dalam rentang perkembanan hidup manusia.

Bredekamp (dalam Ismatul, 2011 hllm. 93) mengemukakan bahwa "dalam batasan yang diberikan oleh The National Assosiation for The Education of Young Children (NAEYC) dikatakan bahwa anak usia dini (early chilhood) adalah anak yang sejak dilahirkan sampai berusia delapan tahun". Berdasarkan pendapat tersebut anak usia dini merupakan anak usia antara 0-8 tahun yang sedang menjalani suatu proses perkembangan dengan pesat. Oleh karena itu, NAEYC mengembangkan berbagai program yang sesuai dengan 
tahapan perkembangan anak sejak seorang anak itu dilahirkan sampai berusia delapan tahun.

\section{Pendidikan Anak Usia Dini}

Pendidikan Anak Usia Dini (PAUD) merupakan pendidikan yang diberikan kepada anak usia dini 0-6 tahun dalam rangka meningkatkan pertumbuhan dan perkembangan anak. Pendidikan anak usia dini adalah suatu upaya pembinaan yang ditujukan kepada anak sejak lahir sampai dengan usia enam tahun yang dilakukan melalui pemberian rangsangan pendidikan untuk membantu pertumbuhan dan perkembangan jasmani dan rohani agar anak memiliki kesiapan dalam memasuki pendidikan lebih lanjut (Undang Undang Nomor 20 Tahun 2003 Pasal 1 Butir 14).

Pendidikan pada anak usia dini pada dasarnya meliputi seluruh upaya dan tindakan yang dilakukan oleh pendidik dan orang tua dalam proses perawatan, pengasuhan, dan pendidikan pada anak dengan menciptakan aura dan lingkungan dimana anak dapat mengeksplorasi pengalaman yang memberikan kesempatan kepadanya untuk mengetahui dan memahami pengalaman belajar yang diperolehnya dari lingkungan, melalui cara mengamati, meniru dan bereksperimen yang berlangsung secara berulang-ulang dan melibatkan seluruh potensi dan kecerdasan anak. Oleh karena anak merupakan pribadi yang unik dan melewati berbagai tahap memberikan kesempatan kepada anak untuk mengeksplorsi berbagai pengalaman dengan berbagai suasana, hendaklah memperhatikan keunikan anak-anak dan disesuaikan dengan tahap perkembangan kepribadian anak (Yuliani, 2013: 7).

Berdasarkan pendapat tersebut, pemdidikan anak usia dini adalah sarana untuk meningkatkan perkembangan dan pertumbuhan anak usia 0-6 tahun agar anak dapat mengetahui pengalaman belajar yang diperolehnya. Upaya tersebut dilakukan oleh guru dan orang tua dalam proses perawatan dan pengasuhan.

\section{Keterampilan Berbahasa}

Menurut Badudu (dalam Dhieni, 2007, hlm. 1.10) bahasa adalah alat penghubung atau komunikasi antara anggota masyarakat yang terdiri dari individu-individu yang menyatakan pikiran, perasaan dan keinginannya. Menurut Stice, Bertrand \& Bertrand (dalam Otto, 2015, hlm.3) bahasa membentuk dasar persepsi, komunikasi, dan interaksi harian kita. Bahasa merupakan suatu sistem simbol yang mengkategorikan, mengorganisasi, dan mengklarifikasi pikiran kita.

Sejalan dengan pendapat tersebut, bahasa adalah alat komunikasi setiap orang untuk mengekspresikan setiap apa keinginan dan apa yang ada pada pikiran dan perasaan setiap orang.

\section{Keterampilan Membaca}

Membaca merupakan suatu
kegiatan atau proses kognitif yang
berupaya untuk menemukan berbagai
informasi yang terdapat dalam tulisan. Farr
$(1984 \cdot 5)$ mengemukakan, "reading is the
heart of education" yang artinya membaca merupakan jantung pendidikan. Dalam hal ini, orang yang sering membaca, pendidikannya akan maju dan ia akan memiliki wawasan yang luas. Menurut Harjasujana dan Mulyati (1997:5-25), membaca merupakan perkembangan keterampilan yang bermula dari kata dan berlanjut kepada membaca kritis. Damaianti (dalam Harras,dkk., 2003:3) mengemukakan bahwa membaca merupakan hasil interaksi antara persepsi 
terhadap lambang-lambang yang mewujudkan bahasa melalui keterampilan berbahasa yang dimiliki pembaca dan pengetahuannya tentang alam sekitar.

\section{Media Educative Game Berbasis Aplikasi} Android

Educative game adalah game yang khusus dirancang untuk mengajarkan user (pemain) suatu pembelajaran tertentu, pengembangan konsep dan pemahaman dan membimbing mereka dalam melatih kemampuan mereka, serta memotivasi mereka untuk memainkannya (Hurd dkk, thn 2009). Menurut Suryadi (2009) Game Edukatif adalah permainan yang dirancang untuk memberikan pendidikan atau pembelajaran kepada pemainnya. Game edukatif dirancang untuk memberi informasi atau pengetahuan. Dapat disimpulkan bahwa educative game adalah suatu game yang dapat memberikan wawasan atau pengajaran yang dapat membuat pemain melatih kemampuan dalam menjalankan suatu permainan.

$$
\text { Leonardi Hartono, dkk. }
$$

Menyebutkan dampak educative game adalah melatih konsentrasi anak, mengajar lebih cepat dan efektif, menambah daya pengertian dan ingatan, membuat proses belajar menyenangkan, membangkitkan emosi anak, meningkatkan kemampuan komunikasi anak, meningkatkan rasa sosialisasi anak. Menurut pemaparan tersebut, educative game dapat memfsilitasi anak untuk mencapai tahapan perkembangannya, salah satunya dapat memfasilitasi anak dalam keterampilan membaca.

Menurut Leonardi Hartono, dkk. Perkembangan industri game saat ini semakin pesat mulai dari munculnya banyak jenis/genre game, perkembangan grafis yang semakin canggih, serta semakin kayanya fitur yang tersedia dalam game. Semakin maraknya game membuat tidak hanya remaja saja yang senang memakainyan, anak-anak pun sekarang ini banyak yang telah mengenal dan bahkan sangat menyukai bermain game. Namun sayangnya banyak game yang dimainkan oleh anak-anak sekarang ini adalah game yang tidak memiliki fungsi pembelajaran.

Tujuan dibuat dan dikembangkannya educative game ini untuk menarik perhatiana anak agar memaikan game yang memiliki fungsi pembelajaran. Salah satunya untuk memfasilitasi anak usia dini dalam keterampilan membaca.

Menurut Dian Wahyu Putra dkk (2016) android adalah sebuah sistem operasi untuk perangkat mobile berbasis linux yang mencakup sistem operasi, middleware, dan aplikasi. Android menyediakan platform terbuka bagi para pengembang untuk menciptakan aplikasi mereka.dari pernyataan tersebut dapat disimpilkan bahwa android adalah suatu fasilitas untuk seseorang membuat aplikasinya sendiri.

\section{METODE}

Penelitian ini bertujuan untuk memfasilitasi keterampilan membaca anak usia 5-6 tahun menggunakan media educative game berbasis aplikasi android. Peneliti menggunakan metode EDR model DBR dengan pendekatan kualitatif.

metode ini lebih tepat dengan tujuan peneliti yaitu merancang, mengembangkan, dan menguji suatu produk sebagai solusi dari suatu permasalahan. Peneliti merancang suatu media untuk memfasilitasi keterampilan 
membaca anak usia 5-6 tahun berupa educative game berbasis aplikasi android.

Adapun karakteristik desain research menurut akker et al, (2006, hal. 5) adalah sebagai berikut:

1) Intervensi (interventionist) : penelitian yang bertujuan untuk merancang suatu intervensi dalam dunia nyata

2) Iteratif (iterative) : penelitian yang menggabungkan siklikal yang meliputi perancangan, evaluasi, dan revisi

3) Orientasi proses (process oriented) : mengabaikan pengukuran inputoutput pada kotak hitam dan memfokuskan pada pemahaman dan pengembangan model intervensi

4) Orientasi utilitas (utility oriented) : mengukur kelebihan dalam rancangan agar dapat digunakan pengguna di lapangan

5) Berorientasi pada teori (theories oriented) : membangun rancangan berdasarkan pada preposisi teoritis kemudian pengujian lapangan di lakukan untuk memberikan kontribusi pada materi

Setting peneliti dilakukan di luar pembelajaran saat jam istirahat diruangan guru di TK Nyimas Oyoh kp. Puteran Ds. Puteran Kecamatan Pagerageung Kabupaten Tasikmalaya dan saat jam belajar anak setelah mengaji di madrasah, dilakukan di rumah salah satu subjek penelitian di rt/rw 002/004 Kp. Puteran Ds.

Puteran Kecamatan Pagerageung Kabupaten Tasikmalaya sebagai tempat pengumpulan data. Pemilihan setting ini dilakukan dengan pertimbangan peneliti untuk menguji media peneliti yaitu educative game berbasis aplikasi android untuk memfasilitasi keterampilan membaca anak usia 5-6 tahun.

Subjek penelitian dalam penelitian ini adalah anak usia 5-6 tahun. Yang menjadi subjek penelitian education game berbasis aplikasi android ini adalah 6 orang anak laki-laki dari TK Nyimas Oyoh kelompok B dan 2 orang anak yang terdiri dari 1 orang laki-laki dan 1 orang perempuan dari lingkungan rumah di Rt/Rw 002/004 Kp. Puteran Ds. Puteran Kec. Pagerageung Kab. Tasikmalaya.

Peneliti menggunakan model Reeves dalam Plomp (2007, hal. 14) dalam melakukan prosedur penelitian.

1) Identifikasi dan analisis masalah oleh peneliti dan praktisi secara kolaboratif

2) Mengembangkan prototype solusi yang di dasarkan pada patokan teori, design principle yang ada dan inovasi teknologi

3) Melakuksn proses berulang untuk menguji dan memperbaiki solusi secara praaktis

4) Refleksi untuk menghsilkan design principle serta meningkatkan implementasi dari solusi secara praktis

\section{TEMUAN DAN PEMBAHASAN}

Pengembangan education game berbasis aplikasi android untuk memfasilitasi keterampilan membaca anak usia 5-6 tahun ini difokuskan pada pengembangan educative game sehingga produk yang dihasilkan adalah educative game berbasis aplikasi android. Penelitian ini menggunakan metode Design Baser Research dengan empat tahapan menurut Reever, yakni: 1) identifikasi dan analisis 
masalah, 2) pengembangan desain produk, 3) uji coba produk, dan 4) refleksi produk.

$$
\text { Penjelasan setiap tahap ini }
$$

berlandaskan pada rumusan masalah yang telah di tentukan.

1) Rumusan masalah pertama berdasarkan identifikasi dan analisis masalah yakni pengembangan educative game berbasis aplikasi android.

2) Rumusan masalah kedua berdasarkan pengembangan desain produk yaitu proses pembuatan educative game berbasis aplikasi android untuk memfasilitasi keterampilan membaca anak usia 5-6 tahun. Adapun tahapantahapannya berupa membuat rancangan pengembangan instrumen, dasar pengembangan produk, menyusun storyboard, pengembangan bentuk produk, dan validasi produk.

3) Sedangkan rumusan masalah ketiga berdasarkan uji coba produk yakni proses uji coba educative game berbasis aplikasi android untuk memfasilitasi keterampilan membaca anak usia 5-6 tahun. Uji produk tahap pertama dilakukan di ruang guru TK Nyimas Oyoh desa Puteran kecamatan Pagerageung kabupaten Tasikmalaya pada hari Jumat, 3 Agustus 2018. Subjek penelitian pada uji coba tahap I ini adalah 6 orang anak laki-laki usia 5-6 tahun. Hasil pada uji coba produk educative game dilihat dari cara anak memainkan educative game dan respon anak terhadap pertanyaan peneliti. Pada saat uji coba tahap I yang dilakukan di ruang guru TK Nimas Oyoh, pertama-tama peneliti meminta izin kepada kepala sekolah dengan menyerahkan surat izin penelitian dari disdik, setelah mendapat izin peneliti menunggu waktu istirahat di karenakan uji coba tidak dilakukan saat pembelajaran berlangsung. Setelah bel istirahat berbunyi sekitar pukul 09.00 WIB, satu persatu anak ditawarkan untuk bermain game oleh peneliti. Ada beberapa anak menolak karena lebih memilih jajan diluar, tetapi saat anak ke-2 melakukan uji produk, banyak anak yang berebut untuk melakukan uji coba produk peneliti. Setelah melakukan uji produk tahap I dan mendapatkan revisi dari validator media, peneliti melakukan uji produk tahap 2. Peneliti melakukan uji produk di lingkungan rumah di rt/rw 002/004 kp. Puteran ds. Puteran kec. Pagerageung kab. Tasikmalaya pada 2 orang anak usia 5-6 tahun yang terdiri dari 1 anak perempuan dan 1 anak laki-laki. Uji produk tahap II dilakukan pada Sabtu, 5 Agustus 2018 di rumah subyek penelitian. Anak sangat antusias dengan produk peneliti karena dapat mengakrabkan antara subyek penelitian dan peneliti. Pertama, peneliti menguji coba produk kepada anak perempuan bernama Intan Audriya kemudian kepada anak laki-laki bernama Fathie Ijjati.

4) Dan rumusan masalah terakhir berdasarkan tahap refleksi produk, yaitu proses refleksi pengembangan educative game berbasis aplikasi android untuk memfasilitasi keterampilan membaca anak usia 5-6 tahun. Setelah peneliti melakukan tiga tahapan pengembangan yaitu, 
identifikasi dan analisis masalah, pengembangan desain produk, validasi produk, dan uji coba produk, ini merupakan tahap terakhir yaitu refleksi produk. Refleksi produk merupakan menghasilkan produk akhir yakni pengembangan educative game berbasis aplikasi android untuk memfasilitasi keterampilan membaca anak usia 5-6 tahun, produk pengembangan educative game berbasis aplikasi android ini bisa di dapatkan dengan mendownload game dengan cara menulis link game yang sebelumnya telah di upload peneliti ke dalam google drive di browser yang terdapat pada perangkat keras berupa smartphone dengan minimal versi jellybean.adapun produk pada pengembangan educative game berbasis aplikasi android ini berupa buku panduan educative game berbasis aplikasi android.

\section{SIMPULAN, IMPLIKASI, DAN} REKOMENDASI

\section{Simpulan}

Berdasarkan hasil pengembangan educative game berbasis aplikasi android untuk memfasilitasi keterampilan membaca anak usia 5-6 tahun maka simpulannya yaitu:

1) Dasar kebutuhan media untuk menfasilitasi keterampilan membaca anak adalah media yang dapat membuat anak tertarik untuk memainkannya. Oleh karena itu, peneliti merancang educative game berbasis aplikasi android karena anak lebih tertarik dengan smartphone

2) Pengembangan educative game berbasis aplikasi android untuk memfasilitasi keterampilan membaca anak usia 5-6 tahun disususn berdasarkan masalah yang ditemukan dari identifikasi dan analisis masalah. Kemudian membuat dasar pengembangan produk lalu membuat storyboard sebagai rancangan awal produk yang kemudian membuat rancangan produk menggunakan software adobe flash player. Setelah pembuatan produk, dilakukan pula validasi produk oleh para ahli. Berdasarkan validasi dari para ahli, produk education game berbasis aplikasi android ini layak untuk di uji cobakan ke lapangan dengan revisi sesuai saran dari ahli

3) Proses uji coba dilakukan sebanyak dua tahap. Tahap I dilakukan kepada subjek 6 orang anak usia 5-6 tahun. Setelah dilakukan uji coba tahap I, dilakukan uji coba tahap II kepada subjek 2 oran anak usia 5-6 tahun dengan saran dan masukan dari validator untuk sedikit memperbaiki kekurangan yang terdapat pada produk. Hasilnya subjek penelitian sangat antusias terhadap produk peneliti dan dapat menggunakannya dengan baik dan tidak ada saran revisi. Oleh karena itu, education game berbasis aplikasi android untuk memfasilitasi keterampilan membaca anak usia 5-6 tahun layak digunakan dalam pembelajaran.

4) Tahap akhir yaitu dengan menghasilkan produk akhir berupa educative game berbasis aplikasi android belajar bersama uvi dan buku panduan education game berbasis aplikasi android belajar bersama uvi. Educative game berbasis aplikasi android untuk memfasilitasi keterampilan membaca anak usia 5-6 tahun ini dapat di dapatkan dengan cara mendownloadnya melalui link yang telah dituliskan dalam buku panduan. 


\section{Implikasi}

Berdasarkan hasil penelitian, implementasi dari pengembangan educative game berbasis aplikasi android untuk memfasilitasi keterampilan membaca anak usia 5-6 tahun adalah sebagai berikut :

1) produk ini dapat dikatakan sebagai solusi untuk menambah fasilitas membaca bagi anak usia 5-6 tahun yang lebih tertarik dengan smartphone

2) produk ini dapat digunakan dimana saja karena produk ini terdapat pada smartphone yang dapat dibawa kemana saja.

\section{Rekomendasi}

Berdasarkan temuan dan pembahasan yang diperoleh dari penelitian ini, rekomendasi dari peneliti diantaranya:

1) Perangkat keras yang akan mengoperasikan produk ini sebaiknya memiliki versi android minimal jellybean

2) orang tua harus mendampingi anak saat bermain educative game ini karena bisa saja anak akan membuka aplikasi lain yang kurang memfasilitasi keterampilan membaca anak

\section{DAFTAR PUSTAKA}

Agustin, C. Dkk. (2015). Aplikasi Game Pendidikan Berbasis Android untuk Memperkenalkan Pakaian Adat Indonesia. Indonesian Journal on Software Engineering, 1 (1), $1-8$.

Andi, T. (2011). Konsep dan Programan Graphical User Interface pada Game. Yogyakarta: C.V ANDI OPSET (penerbit ANDI)
Dalman. (2014). Keterampilan Membaca. Jakarta : RahjaGrafindo Persada

Daswanto, Aldi. (2011). Membuat Mobile Game Edukatif dengan Flash. Bandung: Informatika

Hartono L., Purba K. R., Palit H. N. Pembuatan Game Edukasi Pengenalan Flora dan Fauna Indonesia. Surabaya: Tidak di terbitkan

Hurd, Daniel and Jenuings, Erin. 2009. Standardized Educational Games Rattings: Seggested Criteria. Karya Tulis Ilmiah

Irsa, D. Dkk. (2015). Perancangan Aplikasi Game Edukasi Pembelajaran Anak Usia Dini Menggunakan Linear Congruent Method (LCM) Berbasis Android. Jurnal Informatika Global, 6 (1), 7 - 14

Khasanah, I. Dkk. (2011). Permainan Tradisional Sebagai Media Stimulasi Aspek Perkembangan Anak Usia Dini. Jurnal Penelitian PAUDIA, 1 (1), 91 105

Lidinillah, D. (2012). Educational Design Research: a Theoretical Framework for Action. Tasikmalaya: Universitas Pendidikan Indonesia Kampus Tasikmalaya.

Millah, L. N. (2016). Implementasi Pembelajaran Membaca Permulaan di Taman Kanak-kanak. Bandung: Universitas Pendidikan Indonesia

Permendikbud Nomor 137 tahun 2014 tentang Standar Nasional Pendidikan Anak Usia Dini. 
Puspitasari, R. D. (2014). Upaya Meningkatkan Kemampuan Membaca Dini Anak Kelompok B Melalui Permainan Pohon Huruf. Bandung: Universitas Pendidikan Indonesia

Putra, Dian Wahyu. (2016). Game Edukasi Berbasis Android Sebagai Media Pembelajaran untuk Anak Usia Dini. Jurnal Informatika Merdeka Pasuruan, 1 (1), 46 - 58.

Sauma, A. G. (2016). Rancang Bangun Multimedia Pembelajaran Interaktif Berbasis Game dengan Model CORE (Connecting, Organizing, Reflecting, Extending) untuk Meningkatkan Pemahaman Siswa pada Mata Pelajaran Basis Data. Bandung: Universitas Pendidikan Indonesia

Štemberger ， T. (2014). Design-based research in an educational research context. Journal of Contemporary Educational Studies

Sugiyono. (2017). Metode Penelitian. Bandung : Alfabeta

Suyadi. (2009). Permainan Edukatif yang Mencerdaskan. Yogyakarta: Power Books

Triani, R. P. (2017). Penerapan Multimedia Pembelajaran Berbasis Adventure game dengan Model Core (Connecting, Organizing, Reflecting, Extending) untuk Meningkatkan Pemahaman Siswa dalam Materi Procy Server

Undang-Undang RI No. 20 Tahun 2003 tentang Sistem Pendidikan Nasional (2015). Media Pengembangan
Pendidikan Berbasis Powerpoint untuk Anak Usia Dini. Hlm. 4.

Yuli Yanti Daulay. (2017). Pengembangan Media Pembelajaran Games Edukasi Berbantuan Android pada Materi Alat Optik untuk Siswa SMA. Skripsi 